\title{
Effect of weight loss on urinary incontinence in women
}

This article was published in the following Dove Press journal:

Open Access Journal of Urology

29 July $201 \mathrm{I}$

Number of times this article has been viewed

\section{Emily L Whitcomb Leslee L Subak ${ }^{2}$}

'Southern California Permanente Medical Group, Female Pelvic Medicine and Reconstructive Surgery, Orange County-Irvine Medical Center, Irvine, CA, USA; ${ }^{2}$ University of California San Francisco, UCSF Departments of Obstetrics, Gynecology and Reproductive Sciences, and Urology, and Epidemiology and Biostatistics, SF Veterans Affairs Medical Center, San Francisco, CA, USA
Correspondence: Emily L Whitcomb Southern California Permanente Medical Group, Orange County Irvine Medical Center, Female Pelvic Medicine and Reconstructive Surgery, 6650 Alton Parkway, Irvine, CA 92618

Tel +l 9499325677

Fax + I 9499326348

Email emily.l.whitcomb@kp.org
Background: The purpose of this research was review the epidemiology of the association of obesity and urinary incontinence, and to summarize the published data on the effect of weight loss on urinary incontinence.

Methods: A literature review of the association between urinary incontinence and overweight/ obesity in women was performed. Case series and clinical trials reporting the effect of surgical, behavioral, and/or pharmacological weight loss on urinary incontinence are summarized.

Results: Epidemiological studies demonstrate that obesity is a strong and independent risk factor for prevalent and incident urinary incontinence. There is a clear dose-response effect of weight on urinary incontinence, with each 5-unit increase in body mass index associated with a $20 \%-70 \%$ increase in risk of urinary incontinence. The maximum effect of weight on urinary incontinence has an odds ratio of 4-5. The odds of incident urinary incontinence over $5-10$ years increase by approximately $30 \%-60 \%$ for each 5 -unit increase in body mass index. There appears to be a stronger association between increasing weight and prevalent and incident stress incontinence (including mixed incontinence) than for urge incontinence. Weight loss studies indicate that both surgical and nonsurgical weight loss leads to significant improvements in prevalence, frequency, and/or symptoms of urinary incontinence.

Conclusion: Epidemiological studies document overweight and obesity as important risk factors for urinary incontinence. Weight loss by both surgical and more conservative approaches is effective in reducing urinary incontinence symptoms and should be strongly considered as a first line treatment for overweight and obese women with urinary incontinence.

Keywords: urinary incontinence, obesity, women

\section{Introduction}

Urinary incontinence affects almost $50 \%$ of middle-aged and older women, ${ }^{1,2}$ including approximately 18.3 million women currently in the US, with an estimated increase to 28.4 million women by 2050 as our population increases and ages. ${ }^{3}$ Urinary incontinence is associated with a profound adverse effect on quality of life $\mathrm{e}^{4,5}$ and accounts for more than $\$ 30$ billion in annual direct costs in the US. ${ }^{6}$ Risk factors for urinary incontinence include aging, childbirth, diabetes, and increased body mass index (BMI). ${ }^{7}$

More than $50 \%$ of American women are overweight (BMI: $25-29.9 \mathrm{~kg} / \mathrm{m}^{2}$ ) or obese (BMI: $\geq 30 \mathrm{~kg} / \mathrm{m}^{2}$ ), and the prevalence of obesity is increasing by almost $6 \%$ per year. ${ }^{8}$ Obesity directly contributes to more than 300,000 deaths per year, accounts for expenditure of more than US\$100 billion per year, is associated with medical comorbidities including heart disease, hypertension, diabetes, cancer, and depression, and adversely affects quality of life..$^{8,9}$ 
Obesity is a potentially modifiable risk factor for developing urinary incontinence, with numerous epidemiological studies suggesting that obesity is a strong risk factor. ${ }^{10-13}$ Each 5-unit increase in BMI is associated with a $60 \%$ increase in risk of daily incontinence, and obesity has the largest attributable risk for daily incontinence compared with other risk factors. ${ }^{13}$ Recent data from observational studies and randomized clinical trials demonstrate that weight reduction decreases the frequency of urinary incontinence episodes among overweight and obese women. ${ }^{14}$ Thus, weight loss represents a promising new approach to treatment of urinary incontinence, and one that produces a cascade of broader health improvements in addition to reductions in the frequency of urinary incontinence.

\section{Methods}

We systematically searched for published community-based prevalence studies with bivariate or multivariate analysis of the association between urinary incontinence and overweight/ obesity in women. Prospective case series, longitudinal studies, and randomized, controlled trials of the effect of surgical, behavioral, and pharmacological weight loss on urinary incontinence are summarized. Methods were similar to those described in a recent systematic literature review. ${ }^{15}$ Systematic searches were done using MEDLINE (1966 and thereafter), the Cochrane Central Register of Controlled Trials, the Cochrane Database of Systematic Reviews, and the Database of Abstracts of Reviews of Effects. Searches were updated, thereby including evidence published up to April 2011.

\section{Association of weight and urinary incontinence$$
\text { Observational epidemiological evidence }
$$

Epidemiological studies demonstrate that obesity is a strong risk factor for urinary incontinence. A recent systematic literature review examined the association between urinary incontinence and overweight/obesity in women. ${ }^{15}$ While the definition of urinary incontinence varies according to the study, data from a large number of studies indicate that urinary incontinence in women is associated with higher BMI and weight. ${ }^{10,13,16-29}$ Most studies demonstrate a clear dose-response effect of weight on the prevalence of urinary incontinence, ${ }^{15,16}$ with odds ratios (OR) of 4-5 for the maximum effect of weight on urinary incontinence (Figure 1). A stronger association is reported between increasing weight and stress-predominant incontinence (including mixed incontinence), than for urge-predominant incontinence. ${ }^{12,16,22,27,30}$ Each 5-unit increase in BMI is associated with an approximately $20 \%-70 \%$ increase in risk of daily inco ntinence ${ }^{10,12,13,17,22,25,26}$ and, in one study, obesity had the largest

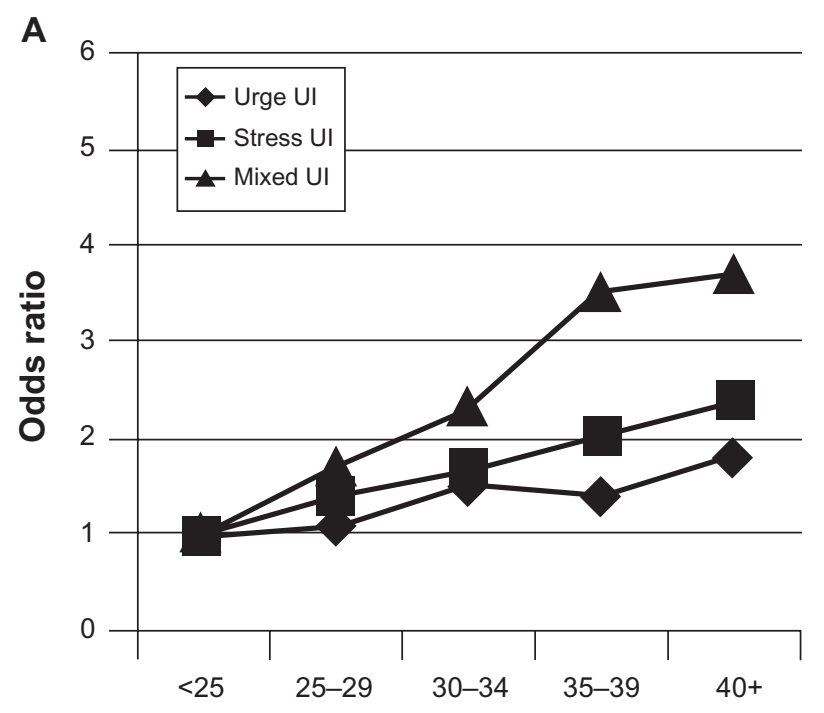

BMI 9

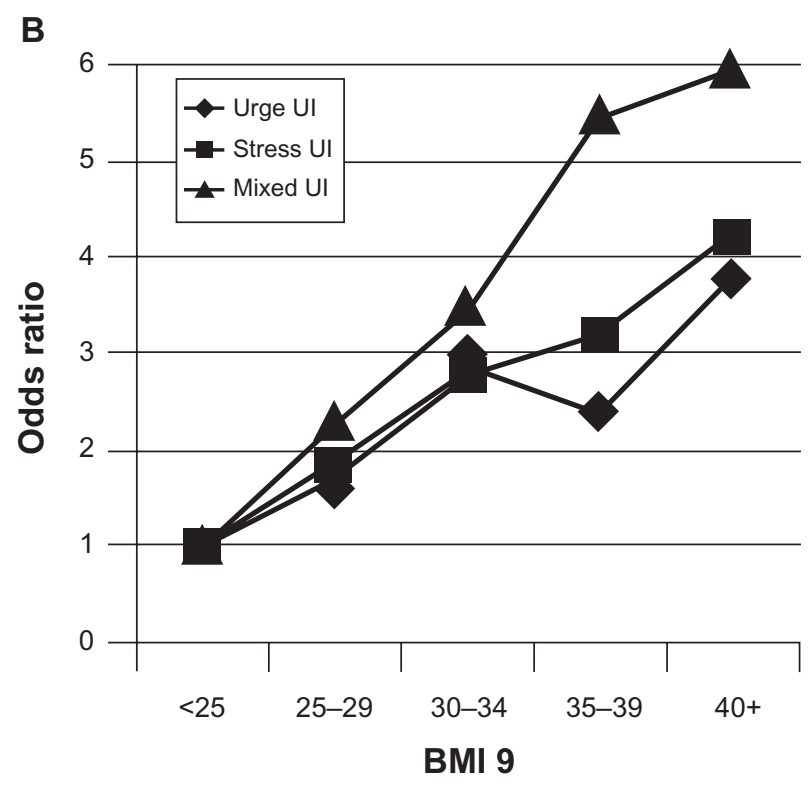

Figure I The association between body mass index (BMI) and prevalent urinary incontinence (UI) by type, adjusted for age, parity, coughing and dyspnea. Values are expressed as odds ratios. Data from Hannestad et al. ${ }^{16}$ A) Any incontinence. B) Severe incontinence.

Reprinted from Journal of Urology, 182(6 Suppl), Subak LL, Richter He, and Hunskaar S, Obesity and Urinary Incontinence: Epidemiology and Clinical Research Update, S2-S7, 2009, (C) with permission from Elsevier. ${ }^{14}$

attributable risk for daily incontinence compared with other risk factors. ${ }^{13}$ Among very obese women planning weight reduction surgery (BMI $>40 \mathrm{~kg} / \mathrm{m}^{2}$ ), the prevalence of incontinence has been reported as $60 \%-70 \%,{ }^{31-35}$ with the prevalence of pure stress incontinence in the range of $28 \%-33 \%$, pure urge incontinence $4 \%-21 \%$, and mixed incontinence $32 \%-46 \%{ }^{31,34}$

\section{Longitudinal studies}

Overweight and obesity have been associated with new onset or incident urinary incontinence in population-based, 
longitudinal cohort studies. Over 5-10 years of follow-up, the odds of incident urinary incontinence increase by approximately $7 \%-12 \%$ for each $1 \mathrm{~kg} / \mathrm{m}^{2}$ unit increase in BMI. ${ }^{36,37}$ The association of incident urinary incontinence with increasing weight is strongest for stress and mixed incontinence and weaker for urge incontinence, and provides evidence for a temporal relationship between a possible cause and an outcome.

A prospective cohort study of women $(n=6424)$ from the UK observed a strong association of BMI with the onset of stress incontinence (OR for overweight and obesity 1.4 and 2.3 , respectively) and overactive bladder ( $\mathrm{OR}$ for overweight and obesity 1.3 and 1.2 , respectively), with only the trend for stress incontinence reaching statistical significance. ${ }^{38,39}$ In a community-based population of women $\geq 50$ years with urge urinary incontinence participating in the Health and Retirement Study, predictors of incident urge urinary incontinence included obesity (OR: 1.6, 95\% confidence interval [CI]: $1.2-2.1) .{ }^{40}$ In a 5-year annual follow-up of 3301 women aged 42-52 years, incident incontinence was found in 56\%, for an annual incidence of $11 \%$ per year. ${ }^{36}$ Multivariate analyses showed that each unit of BMI was associated with any (OR: 1.05, 95\% CI: 1.02-1.07), frequent (OR: 1.12, 95\% CI: 1.06-1.19), stress (OR: 1.06, 95\% CI: 1.03-1.10), urgency (OR: 1.03, 95\% CI: 1.01-1.06), and mixed (OR: 1.09, 95\% CI: 1.04-1.13) urinary incontinence. In the Nurses' Health Study II ( $\mathrm{n}=35,754)$, increasing BMI was associated with higher odds of incident urinary incontinence. ${ }^{37}$ Comparing women with BMI $\geq 35$, in those with BMI 21.0-22.9, the OR for at least monthly urinary incontinence was $2.11(95 \%$ CI: 1.84-2.42), at least weekly urinary incontinence 3.85 (95\% CI: $3.05-4.85$ ), and severe urinary incontinence 5.52 (95\% CI: 3.72-8.18).

\section{Weight gain and incident urinary incontinence}

The odds of incident urinary incontinence also increase with increasing adult weight gain. ${ }^{37}$ Compared with women who maintained their weight within $2 \mathrm{~kg}$, the OR for at least weekly incontinence was 1.44 (95\% CI: 1.05-1.97) among women who gained 5.1-10.0 kg and 4.04 (95\% CI: 2.93-5.56) among women who gained more than $30 \mathrm{~kg}$ since early adulthood $(P<0.001$ for trend). Compared with women having a BMI of 21.0-22.9, women with BMI $\geq 35$ had an OR for stress incontinence of 3.42 (95\% CI: 2.48-4.72), 6.10 for urge incontinence (95\% CI: 3.11-11.98), and 5.60 for mixed incontinence (95\% CI: 3.17-9.88). In a longitudinal study of 1201 British women, high BMI at age 20-36 years was associated with stress urinary incontinence and severe urinary incontinence in midlife. Longstanding overweight was a stronger predictor than becoming overweight/obese after the age of 43 years (OR: 1.85, 95\% CI: 0.97-3.51). ${ }^{29}$

\section{Body fat distribution and urinary incontinence}

Little is known about the association of fat distribution, for example, abdominal adiposity estimated by waist circumference or waist-hip ratio, with urinary incontinence. In multivariable analyses including BMI, increasing waisthip ratio has been found to be an independent risk factor for stress incontinence (OR: 1.18 per 0.1 unit), but not for urge and mixed incontinence. ${ }^{12}$ Among a cohort of Korean women, compared with women in the lowest quartile of waist circumference, the ORs for stress incontinence increased significantly in a dose-dependent relationship (1.79, 3.50, and 6.07 for the next quartiles, respectively) after adjustments for BMI. ${ }^{21}$ Among women in the Nurses' Health Study, there were highly significant trends of increasing risk of incontinence with both increasing BMI and waist circumference. ${ }^{41}$ When BMI and waist circumference were included in models simultaneously, BMI was associated with urgency and mixed incontinence, but not stress incontinence. Waist circumference was associated only with stress incontinence. In the EPINCONT study of 6876 incontinent Norwegian women, multivariable analyses adjusting for age, parity, and BMI showed a statistically significant association between waist-hip ratio and any incontinence and mixed incontinence (both OR: 1.1 per 0.1 unit). ${ }^{42}$ In the American Boston Area Community Health survey, each $10-\mathrm{cm}$ increase in waist circumference in women was independently associated with higher prevalence of weekly urinary incontinence (OR: 1.15, 95\% CI: $1.01-1.31) .{ }^{43}$

\section{Treatment options for urinary incontinence}

The mainstay of treatment for both stress and urge urinary incontinence is bladder training, toileting assistance, and/or pelvic muscle rehabilitation. ${ }^{44} 46$ These behavioral approaches are only modestly effective, and in many cases, a second line of therapy is needed. Second-line treatment for stress incontinence is frequently surgical. Among 665 women enrolled in a clinical trial of the Burch and pubovaginal sling procedures, objective stress incontinence cure rates decreased from almost $100 \%$ after surgery to $50 \%-65 \%$ over 2 years. ${ }^{47}$ In a randomized equivalence trial of 597 women with stress incontinence assigned to either retropubic or transobturator 
midurethral slings, the rates of objective treatment success at 12 months were $80 \%$ in the retropubic sling group and $77 \%$ in the transobturator sling group. ${ }^{48}$ Although surgery is effective, it is associated with discomfort and a prolonged recovery period, and incontinence may recur over time. ${ }^{49,50}$ Concerns about higher rates of failure and operative complications in obese women have led to debate about the role of surgery in this population, although the safety and effectiveness of continence surgery in obese women has been supported by the literature..$^{51-57}$ In addition, many women prefer not to have surgery, and others, particularly obese women, are poor surgical candidates. Pharmacological therapy, primarily with anticholinergic or antimuscarinic medications, is frequently the second line of therapy for urge urinary incontinence and results in a $15 \%-60 \%$ reduction in weekly incontinent episodes. However, anticholinergic side effects are common and the medications must be taken chronically. ${ }^{58-61}$ Newer medications and reformulations of older drugs provide better tolerability, but long-term compliance remains low. ${ }^{62,63}$ Approved implantable neurostimulator devices and sacral neuromodulation and intravesical botulinum toxin type A injection represent newer alternatives for the management of refractory urge urinary incontinence that have been used with success, but are more invasive and costly, ${ }^{64-66}$ and in the case of the latter, not yet approved by the Food and Drug Administration. New and novel treatment strategies for urinary incontinence are important to improve efficacy and provide acceptable therapeutic options for women.

\section{Effect of weight loss on urinary incontinence}

Because obesity is a potentially modifiable risk factor for urinary incontinence, weight reduction has been shown to be an effective treatment option. A beneficial effect of weight loss on the prevalence and frequency of incontinence has been found in surgical and behavioral weight reduction interventions (Table 1). ${ }^{14,15}$

\section{Surgical weight loss}

In observational studies, severely obese women $(>45 \mathrm{~kg}$ above ideal weight) with incontinence who had dramatic weight loss after bariatric surgery $(45-50 \mathrm{~kg})$ had significant improvement in urinary incontinence. ${ }^{32,67,68}$ In one study $(n=138)$, the prevalence of stress urinary incontinence decreased from $61 \%$ at baseline to $12 \%(P<0.001)$ after stabilization of weight over $2-5$ years, ${ }^{32}$ and in a second study $(\mathrm{n}=101)$, the prevalence of any incontinence decreased from $67 \%$ at baseline to $37 \%$ at 12 months $(P<0.001) .{ }^{31}$ In another surgical cohort undergoing bariatric surgery, the prevalence of pelvic floor disorder symptoms including urinary incontinence improved from $87 \%$ before surgery to $65 \%$ after surgery. ${ }^{35}$ In a morbidly obese cohort undergoing bariatric surgery with an average weight loss of $49 \mathrm{~kg}$, there was a significant improvement in stress incontinence $(P<0.001)$, frequency and leakage of any degree, and overall quality of life subsequent to surgery. ${ }^{69}$ In a cohort of 253 morbidly obese patients undergoing laparoscopic sleeve gastrectomy, stress urinary incontinence was reported preoperatively in $60(32 \%)$ females, and complete resolution or improvement was reported in $54(90 \%)$ patients. $^{70}$ Statistically significant changes have also been observed in urodynamic parameters, ${ }^{68,71}$ frequency of incontinence episodes, and the need to use absorptive pads. ${ }^{67}$

\section{Behavioral weight loss}

Decreased frequency of urinary incontinence episodes has also been observed following enrollment in behavioral weight loss programs, including very low calorie liquid diet and intensive lifestyle diet and exercise interventions. ${ }^{71-74}$ In a small prospective cohort study of overweight and obese incontinent women enrolled in very low calorie liquid diet weight reduction programs, six of six women achieving a weight loss of $\geq 5 \%$ had at least a $50 \%$ reduction in frequency of urinary incontinence compared with one of four women with $<5 \%$ weight loss $(P=0.03) .{ }^{71}$ A randomized trial of a 3-month, very low calorie liquid diet program compared with no intervention $(n=42)$ found greater weight loss among women randomized to the diet interventioncompared with controls (14 kg vs $0 \mathrm{~kg}$ ) and a greater decrease in weekly frequency of incontinence episodes from baseline (60\% vs $15 \% ; P<0.001)$, with decreases observed in both stress $(P=0.003)$ and urge $(P=0.03)$ incontinent episodes. ${ }^{72}$ The weight and urinary incontinence decreases were maintained for 6 months.

Overweight prediabetic women enrolled in the Diabetes Prevention Program $(n=1957)$ were randomized to intensive lifestyle therapy, metformin, or placebo with standard lifestyle advice. ${ }^{73}$ At almost 3 years of follow-up, the prevalence of total weekly incontinence was lower among women in the intensive lifestyle group (38\%) than those randomized to metformin (48\%) or placebo $(46 \% ; P<0.001)$. This difference was most apparent among women with stress incontinence $(31 \%$ for intensive lifestyle group vs $40 \%$ for metformin vs $37 \%$ for placebo, $P=0.006)$. Change in weight accounted for almost all of the incontinence effect explained (35\%), with change in exercise and incident diabetes each explaining only $5 \%$. 
Table I The effects of weight loss on urinary incontinence

\begin{tabular}{|c|c|c|c|c|c|}
\hline Study & $\mathbf{N}$ & Design, f/u & $\begin{array}{l}\text { Change in BMI } \\
\text { (or wt) } \ddagger\end{array}$ & $\begin{array}{l}\text { Change in prevalent } \\
\text { UI or UI episodest }\end{array}$ & Other outcomes \\
\hline \multicolumn{6}{|c|}{ Case series and cohort studies of surgical weight loss } \\
\hline $\begin{array}{l}\text { Deitel } \\
\text { et al }{ }^{32}\end{array}$ & 138 & Unknown & 124 to $79 \mathrm{~kg}$ & $\begin{array}{l}61 \% \text { to } 12 \% \text {, prevalent } \\
\text { stress UI }(P<0.001)\end{array}$ & $\begin{array}{l}\text { Infertility and menstrual } \\
\text { irregularities improved }\end{array}$ \\
\hline $\begin{array}{l}\text { Bump } \\
\text { et } \mathrm{al}^{67}\end{array}$ & 13 & 12 months & $\begin{array}{l}\text { BMI: } 49 \text { to } 33 \\
\text { (I32 to } 88 \mathrm{~kg})\end{array}$ & $\begin{array}{l}92 \% \text { to } 23 \% \text { prevalent } \\
\text { UI }(P=0.004)\end{array}$ & $\begin{array}{l}\text { Differences seen in: } \\
\text { - urodynamic parameters } \\
\text { - urethral mobility }\end{array}$ \\
\hline $\begin{array}{l}\text { Sugerman } \\
\text { et al }{ }^{68}\end{array}$ & 15 & 12 months & $\begin{array}{l}\text { BMI: } 52 \text { to } 33 \\
\text { (I } 40 \text { to } 87 \mathrm{~kg})\end{array}$ & $\begin{array}{l}47 \% \text { to } 0 \% \text { prevalent } \\
\text { UI }(P<0.00 \mathrm{I})\end{array}$ & $\begin{array}{l}\text { Significant changes in: } \\
\text { - sagittal abdominal diameter } \\
\quad(32 \text { to } 20 \mathrm{~cm}, P<0.000 \mathrm{I}) \\
\text { - urinary bladder pressure } \\
\text { (I7 to } 10 \mathrm{~cm} \mathrm{H} \mathrm{O}, P<0.00 \mathrm{I})\end{array}$ \\
\hline $\begin{array}{l}\text { Frigg } \\
\text { et al }{ }^{100}\end{array}$ & 233 & 44 months & $\begin{array}{l}\text { Excess wt loss at } \\
4 \text { year f/u was } 54 \%\end{array}$ & $\begin{array}{l}26 \% \text { to II \% prevalent } \\
\text { stress UI at } 2 \text { years f/u }\end{array}$ & $\begin{array}{l}\text { Improvements in other medical } \\
\text { comorbidities }\end{array}$ \\
\hline $\begin{array}{l}\text { Burgio } \\
\text { et } \mathrm{al}^{31}\end{array}$ & 101 & 12 months & BMI: 49 to 30 & $67 \%$ to $37 \%(P<0.001)$ & $\begin{array}{l}\text { - FI prevalence decreased, } 19 \% \\
\text { to } 9 \%(P=0.018) \\
\text { - Decrease in UI significantly } \\
\text { associated with BMI }\end{array}$ \\
\hline $\begin{array}{l}\text { Vella } \\
\text { et al }{ }^{69}\end{array}$ & 126 & 20 months & BMI: 47.5 to 31 & $\begin{array}{l}\text { Improvement in stress } \\
\text { incontinence ( } 45 \% \text { to } 20 \%) \text {, } \\
\text { frequency and leakage } \\
\text { of any degree }\end{array}$ & $\begin{array}{l}\text { Improvement in overall quality } \\
\text { of life }\end{array}$ \\
\hline $\begin{array}{l}\text { Srinivasa } \\
\text { et } \mathrm{al}^{70}\end{array}$ & 171 & 12 months & $\begin{array}{l}41 \mathrm{~kg} \text {, mean excess } \\
\text { BMl loss } 59 \%\end{array}$ & $\begin{array}{l}\text { Stress UI preoperatively } \\
\text { in } 60(32 \%), \text { complete } \\
\text { resolution or improvement } \\
\text { was reported in } 54 \\
(90 \%) \text { patients }\end{array}$ & \\
\hline \multicolumn{6}{|c|}{ Cohort studies and randomized trials of nonsurgical weight loss on UI } \\
\hline $\begin{array}{l}\text { Subak } \\
\text { et } \mathrm{al}^{71}\end{array}$ & 10 & $\begin{array}{l}\text { Cohort: very } \\
\text { low calorie } \\
\text { liquid diet } \\
\text { wt loss program } \\
3 \text { month } \mathrm{f} / \mathrm{u}\end{array}$ & $\begin{array}{l}\text { BMI: mean } 38 \text { to } 33 \\
(-14 \mathrm{~kg} ; P<0.03)\end{array}$ & $\begin{array}{l}\text { I } 3 \text { to } 8 \mathrm{UI} \text { episodes } \\
\text { per week after wt loss } \\
(P<0.07)\end{array}$ & $\begin{array}{l}\text { All women losing } \geq 5 \% \text { body wt } \\
(6 \text { of } 10) \text { had }>50 \% \text { reduction in } \\
\text { Ul frequency }(P<0.03)\end{array}$ \\
\hline $\begin{array}{l}\text { Subak } \\
\text { et } \mathrm{al}^{72}\end{array}$ & 40 & $\begin{array}{l}\text { Randomized to: } \\
\text { I. Very low calorie } \\
\text { liquid diet } \\
(n=20) \\
\text { 2. Control } \\
(n=20) \\
3 \text { month intervention, } \\
9 \text { month f/u }\end{array}$ & $\begin{array}{l}\text { Wt change by group } \\
(3 \text { months): } \\
\text { I. }-16 \mathrm{~kg} \\
\text { 2. No change } \\
P<0.0001\end{array}$ & $\begin{array}{l}\text { Reduction in weekly } \\
\text { Ul episodes ( } 3 \text { months): } \\
\text { I. } 60 \% \\
\text { 2. } 15 \% \\
P<0.0005\end{array}$ & $\begin{array}{l}\text { - Stress }(P=0.003) \text { and urge } \\
\quad(P=0.03) \text { Ul episode } \\
\text { frequency decreased in Group } \\
\text { I vs Group } 2 \\
\text { - Group } 2 \text { had the intervention } \\
\text { after } 3 \text { months: } 71 \% \text { reduction } \\
\text { in weekly UI after wt loss } \\
\text { - Significant improvement in IIQ } \\
\text { and UDI scores after wt loss }\end{array}$ \\
\hline $\begin{array}{l}\text { Brown } \\
\text { et } \mathrm{al}^{73}\end{array}$ & 1957 & $\begin{array}{l}\text { Randomized to: } \\
\text { I. Lifestyle intervention* } \\
(n=660) \\
\text { 2. Metformin } \\
(n=636) \\
\text { 3. Placebo }(n=66 \mathrm{I}) \\
2.9 \text { years mean f/u }\end{array}$ & $\begin{array}{l}\text { Wt change by group: } \\
\text { I. }-3.4 \mathrm{~kg} \\
2 .-1.5 \mathrm{~kg} \\
3 .+0.5 \mathrm{~kg} \\
P<0.00 \mathrm{I}\end{array}$ & $\begin{array}{l}\text { Prevalence of weekly UI: } \\
\text { I. } 38 \% \\
\text { 2. } 48 \% \\
\text { 3. } 46 \% \\
P=0.00 \mathrm{I}\end{array}$ & $\begin{array}{l}\text { - Weekly stress UI was lower } \\
\text { in Group I ( } 31 \% \text { vs } 40 \% \text { in } \\
\text { Group in } 2 \text { and } 37 \% \text { in } \\
\text { Group } 3 ; P=0.006) \\
\text { - No difference in prevalent } \\
\text { urge UI by randomized group } \\
\text { (24\%, } 29 \%, 26 \% \text { for groups I, } \\
2 \text {, and } 3 ; P=0.12 \text { ) }\end{array}$ \\
\hline $\begin{array}{l}\text { Auwad } \\
\text { et al }{ }^{75}\end{array}$ & 64 & $\begin{array}{l}\text { Cohort: low calorie } \\
\text { diet, exercise, Orlistat } \\
(\mathrm{N}=40) \text {. } \\
\text { Included } 42(65 \%) \\
\text { women with } \geq 5 \% \\
\text { wt loss in analyses }\end{array}$ & $\begin{array}{l}\text { BMI: median } \\
36.2 \text { to } 31.9 \\
(8.8 \mathrm{~kg}) \text { at } \\
18 \text { months }\end{array}$ & $\begin{array}{l}\text { 24-hour pad test wt } \\
\text { median } 38.8 \text { to } 18.5 \mathrm{gm} \\
(P<0.00 \mathrm{I})\end{array}$ & $\begin{array}{l}\text { After } \geq 5 \% \text { wt loss, decrease in } \\
\text { nocturia, bladder neck mobility, } \\
\text { and all domains of the Kings } \\
\text { Health Questionnaire } \\
\text { (all } P<0.05 \text { ). }\end{array}$ \\
\hline
\end{tabular}


Table I (Continued)

\begin{tabular}{|c|c|c|c|c|c|}
\hline Study & $\mathbf{N}$ & Design, f/u & $\begin{array}{l}\text { Change in BMI } \\
\text { (or wt) })^{\ddagger}\end{array}$ & $\begin{array}{l}\text { Change in prevalent } \\
\text { UI or UI episodes }{ }^{\dagger}\end{array}$ & Other outcomes \\
\hline $\begin{array}{l}\text { Subak et } \mathrm{al}^{74} \\
\text { Wing et } \mathrm{al}^{76}\end{array}$ & 338 & $\begin{array}{l}\text { Randomized to: } \\
\text { I. } 6 \text { month lifestyle } \\
\text { intervention, } 12 \text { month } \\
\text { maintenance* } \\
(\mathrm{n}=226) \\
\text { 2. Structured education } \\
\text { program }(\mathrm{n}=\mathrm{I} / 2) \\
18 \text { month } \mathrm{f} / \mathrm{u}\end{array}$ & $\begin{array}{l}6 \text { months: } \\
\text { Wt change by group: } \\
\text { I. }-7.8 \mathrm{~kg}(8 \%) \\
\text { 2. }-1.5 \mathrm{~kg}(\mathrm{I} .6 \%) \\
P<0.00 \mathrm{I}\end{array}$ & $\begin{array}{l}\text { Reduction in weekly } \\
\text { total UI/stress UI: } \\
\text { I. } 47 \% / 58 \% \\
\text { 2. } 28 \% / 33 \% \\
P=0.01 /<0.02\end{array}$ & $\begin{array}{l}\text { Higher proportion of Group I } \\
\text { vs Group } 2 \text { had: } \\
\text { - } \geq 70 \% \text { reduction in frequency } \\
\text { of all }(P<0.00 \mathrm{I}) \text {, stress } \\
(P=0.009) \text { and urge }(P=0.04) \\
\text { Ul episodes } \\
\text { - greater perceived } \\
\text { improvement UI frequency, } \\
\text { lower volume of urine lost, } \\
\text { Ul as a less of a problem, and } \\
\text { higher satisfaction with the } \\
\text { change in their UI } \\
\text { (all } P<0.00 \mathrm{I})\end{array}$ \\
\hline & & & $\begin{array}{l}\text { I } 8 \text { months: } \\
\text { Wt change by group: } \\
\text { I. }-5.5 \% \\
\text { 2. }-1.6 \% \\
P<0.00 \text { I }\end{array}$ & $\begin{array}{l}\geq 70 \% \text { reduction in } \\
\text { frequency of urge } \\
\text { Ul episodes: } \\
\text { I. } 47 \% / 34 \% \\
P=0.03\end{array}$ & $\begin{array}{l}\text { Higher proportion of Group I } \\
\text { vs Group } 2 \text { had: } \\
\text { - greater perceived lower } \\
\text { volume of urine lost, UI as a } \\
\text { less of a problem, and higher } \\
\text { satisfaction with the change in } \\
\text { their UI (all } P<0.05 \text { ) }\end{array}$ \\
\hline
\end{tabular}

Notes: *Lifestyle intervention included diet, exercise, and behavior modification program; ${ }^{\text {Mean }}$ change unless otherwise specified; ${ }^{\dagger}$ Percent change.

Abbreviations: Ul, urinary incontinence; Fl, fecal incontinence; UDI, Urogenital Distress Inventory; IIQ, Incontinence Impact Questionnaire; f/u, follow-up; wt, weight. Reprinted from Journal of Urology, I82(6 Suppl), Subak LL, Richter HE, and Hunskaar S, Obesity and Urinary Incontinence: Epidemiology and Clinical Research Update, S2-S7, 2009, (c) with permission from Elsevier. ${ }^{14}$

In a prospective longitudinal study of 64 obese women with urodynamic stress urinary incontinence participating in a low calorie diet and exercise program with addition of orlistat, the antiobesity drug, offered to those who did not achieve a target loss of 5\%-10\%, weight loss of at least $5 \%$ was associated with significant reduction in pad test loss (median difference, $19 \mathrm{~g} ; 95 \% \mathrm{CI}: 13-28 \mathrm{~g} ; P<0.001$ ). There was also a clinical and statistically significant improvement in quality of life measures. ${ }^{75}$

The first large randomized trial on the effect of weight reduction on urinary incontinence included 338 overweight and obese women with at least ten urinary incontinence episodes per week randomized to an intensive 6-month weight loss program (diet, exercise, and behavior modification, $\mathrm{n}=226)$ or to a structured education program $(\mathrm{n}=112){ }^{74}$ After 6 months, women in the intervention group achieved a mean weight loss of $8 \%$ compared with $2 \%$ in the control group $(P<0.0001)$, and the mean number of weekly incontinence episodes decreased by $47 \%$ in the intervention group compared with $28 \%$ in the control group $(P=0.01)$. As compared with the control group, the intervention group had a greater decrease in the frequency of stress incontinence episodes $(P=0.02)$, but not of urge incontinence episodes $(P=0.14)$. At 12 months, the intervention group reported a greater percent reduction in weekly stress urinary incontinence episodes ( $65 \%$ vs $47 \%, P<0.001)$ and a greater proportion achieved at least a $70 \%$ decrease in weekly total and stress urinary incontinence episodes compared with controls. By 18 months, a greater proportion of women in the intervention group had at least a $70 \%$ improvement in urge incontinence episodes, but there were no significant differences between the groups for stress or total urinary incontinence. The intervention group also reported greater satisfaction with changes in urinary incontinence than the control group at 6,12 , and 18 months. $^{76}$

\section{Mechanism of the obesity- incontinence association}

While the mechanism of the obesity-urinary incontinence association is unknown, it is theorized that excess body weight increases abdominal pressure, which in turn increases bladder pressure and urethral mobility, leading to stress urinary incontinence, and also exacerbates detrusor instability and overactive bladder. ${ }^{67,72}$ Although a mechanical mechanism has been proposed for stress urinary incontinence in overweight and obese women, an inflammatory response in the urinary bladder has been proposed for overactive bladder. Elevated levels of urine biomarkers involved in inflammation and tissue repair have suggested a role for inflammation in overactive bladder. ${ }^{77}$ Obesity induced by diet has also been shown to be 
associated with macrophage infiltration into adipose tissue, ${ }^{78}$ a process which has been proposed to affect adipocytes surrounding the human bladder, leading to inflammation and overactive bladder symptoms. ${ }^{79}$ The underlying mechanism may also be related to lower levels of circulating ghrelin levels associated with obesity that adversely affect urethral support and detrusor contractility. ${ }^{79-81}$ Comorbid diabetes mellitus, closely linked to obesity, is also a risk factor for both stress and urge urinary incontinence in obese women; ${ }^{14,30}$ the microvascular compromise induced by diabetes in obese women may adversely affect the continence mechanism or bladder "sensitivity". ${ }^{79}$ Additionally, obesity, like pregnancy, may cause chronic strain, stretching and weakening of the muscles, nerves, and other structures of the pelvic floor that may lead to dysfunction of the continence mechanism, and place obese women at risk for incontinence. ${ }^{82,83}$

Strong associations between BMI and intra-abdominal pressure (Pearson's coefficient correlation 0.76) and intravesical pressure (Pearson's coefficient correlation 0.71 ) have been observed.$^{84}$ In addition, weight loss is associated with changes in urodynamic parameters. Following large, surgically induced weight loss, statistically significant changes have been reported in urodynamic parameters, including decreased intravesical pressure, magnitude of bladder pressure increases with coughing, bladder-to-urethra pressure transmission with cough, and urethral axial mobility, ${ }^{67,68}$ supporting the theory of increased abdominal pressure. With moderate weight loss ( $13 \%$ of baseline weight), significant correlations between weight change and decreased initial intravesical pressure (Spearman's $r=0.52, P=0.01$ ), decreased intravesical pressure at maximum capacity $(r=0.62, P=0.001)$ and increased Valsalva leak point pressure $(r=0.57, P=0.03)$ have been observed. ${ }^{72}$ In a study aimed at describing the urodynamic characteristics of overweight and obese women with urinary incontinence participating in the Program to Reduce Incontinence by Diet and Exercise (PRIDE), intra-abdominal pressure at maximum cystometric capacity increased $0.4 \mathrm{~cm} \mathrm{H_{2 }} \mathrm{O}$ per $\mathrm{kg} / \mathrm{m}^{2}$ unit of $\mathrm{BMI}$ and $0.4 \mathrm{~cm} \mathrm{H}_{2} \mathrm{O}$ per $2 \mathrm{~cm}$ increase in abdominal circumference, and intravesical pressure at maximum cystometric capacity increased $0.4 \mathrm{~cm} \mathrm{H}_{2} \mathrm{O}$ per 2-cm increase in abdominal circumference, but was not associated with BMI. ${ }^{85}$

\section{Patient-focused perspectives}

Urinary incontinence has been associated with a profound adverse effect on overall and health-related quality of life, ${ }^{86,87}$ a 20\%-30\% increased risk of falls and fractures, ${ }^{88,89}$ and dramatic limitations in daily functioning. ${ }^{2,4,5,90-93}$ In a systematic review of the literature on quality of life among women with urinary incontinence, factors influencing quality of life were age, severity of urinary incontinence, type of urinary incontinence, frequency of urinary incontinence episodes, body weight, stress, and help-seeking behavior. ${ }^{91}$ In a crosssectional study of 5530 eligible respondents to a mail survey, one of the strongest predictors of urinary incontinence was obesity, and urinary incontinence had a stronger influence on quality of life than diabetes, cancer, and arthritis. ${ }^{94}$

Although there are many studies quantifying the effect of incontinence on general and incontinence-specific quality of life using instruments like the Short Form (SF-36) Health Survey ${ }^{95}$ and Incontinence Impact Questionnaire, ${ }^{96}$ respectively, there are few data on the impact of urinary incontinence on health-related quality of life measured by health utilities instruments, an important outcome for cost-utility analyses. Incontinence, Alzheimer's disease, and stroke are self-assessed as the three chronic health conditions that most adversely affect women's health-related quality of life. ${ }^{6,97,98}$ In addition, obesity itself is associated with increased risk for coronary heart disease, hypertension, diabetes, cancer, dyslipidemia, stroke, liver or gallbladder disease, sleep apnea and respiratory disease, osteoarthritis, and depression., ${ }^{9,99}$ Thus, women who are both overweight and incontinent are at tremendous risk for negative health outcomes and impaired quality of life.

In the PRIDE study, ${ }^{74}$ several patient-focused perspectives were assessed. Women in the weight loss group perceived greater improvement in the frequency of their urinary incontinence, lower volume of urine lost, incontinence as a less of a problem, and higher satisfaction with the change in their incontinence at 6 months compared with women in the control group $(P<0.001)$ at 6 months $^{74}$ and 18 months. $^{76}$ Therefore, weight loss, a treatment approach that can impact both incontinence and obesity, is an exciting new treatment direction for this population and has tremendous implications for general and health-related quality of life.

\section{Conclusion}

Epidemiological studies demonstrate that obesity is a strong, independent, and modifiable risk factor for prevalent and incident urinary incontinence. There is a clear doseresponse effect of weight on prevalent and incident urinary incontinence. There appears to be a stronger association between increasing weight and prevalent and incident stress incontinence (including mixed incontinence) than for urge incontinence and overactive bladder syndrome. However, the precise mechanism of the association between obesity and incontinence is unknown, and additional neurophysiologic 
and urodynamic studies are needed to define better the obesity-urinary incontinence relationship.

Weight loss studies indicate that both surgical and nonsurgical weight loss leads to significant improvements in urinary incontinence symptoms. Data support that weight loss of 5\%-10\% has an efficacy similar to that of other nonsurgical urinary incontinence treatments and should be strongly considered as a first-line therapy for incontinence. In addition, moderate weight reduction is associated with extensive health improvements.

\section{Future directions}

High priorities for future research include well designed observational studies and intervention trials to examine the effectiveness of weight loss for urinary incontinence in a general population of overweight and obese women with urinary incontinence; assess the comparative effectiveness of standard surgical, pharmacological, and behavioral urinary incontinence treatments in overweight and obese women; evaluate if healthier lifestyle choices, such as weight control and physical activity, are effective to prevent the onset or worsening of urinary incontinence in women; explore the mechanisms of how weight affects urinary incontinence and weight loss improves urinary incontinence; and, examine the role of adipocytokines, inflammation or other biologically active substances in the weight-urinary incontinence association. In addition, measures of urinary incontinence could be included in studies of weight loss and behavioral/lifestyle interventions to document further the effect of these interventions on urinary incontinence, better characterize women likely to benefit from weight loss, and determine if urinary incontinence improvements can be sustained with long-term weight reduction.

\section{Disclosure}

The authors report no conflicts of interest in this work.

\section{References}

1. Thom DH, van den Eeden SK, Ragins AI, et al. Differences in prevalence of urinary incontinence by race/ethnicity. J Urol. 2006;175(1):259-264.

2. Wetle T, Scherr P, Branch LG, et al. Difficulty with holding urine among older persons in a geographically defined community: prevalence and correlates. J Am Geriatr Soc. 1995;43(4):349-355.

3. Wu JM, Hundley AF, Fulton RG, Myers ER. Forecasting the prevalence of pelvic floor disorders in US Women: 2010 to 2050. Obstet Gynecol. 2009;114(6):1278-1283.

4. Grimby A, Milsom I, Molander U, Wiklund I, Ekelund P. The influence of urinary incontinence on the quality of life of elderly women. Age Ageing. 1993;22(2):82-89.

5. Hunskaar S, Vinsnes A. The quality of life in women with urinary incontinence as measured by the sickness impact profile. J Am Geriatr Soc. 1991;39(4):378-382.
6. Wilson L, Brown JS, Shin GP, Luc KO, Subak LL. Annual direct cost of urinary incontinence. Obstet Gynecol. 2001;98(3):398-406.

7. Buckley BS, Lapitan MC. Prevalence of urinary incontinence in men, women, and children - current evidence: findings of the Fourth International Consultation on Incontinence. Urology. 2010; 76(2):265-270.

8. Mokdad AH, Ford ES, Bowman BA, et al. Prevalence of obesity, diabetes, and obesity-related health risk factors, 2001. JAMA. 2003;289(1):76-79.

9. Allison DB, Fontaine KR, Manson JE, Stevens J, VanItallie TB. Annual deaths attributable to obesity in the United States. JAMA. 1999;282(16):1530-1538.

10. Mommsen S, Foldspang A. Body mass index and adult female urinary incontinence. World J Urol. 1994;12(6):319-322.

11. Moller LA, Lose G, Jorgensen T. Risk factors for lower urinary tract symptoms in women 40 to 60 years of age. Obstet Gynecol. 2000;96(3):446-451.

12. Brown J, Grady D, Ouslander J, Herzog A, Varner R, Posner S. Prevalence of urinary incontinence and associated risk factors in postmenopausal women. Heart and Estrogen/Progestin Replacement Study (HERS) Research Group. Obstet Gynecol. 1999;94(1):66-70.

13. Brown J, Seeley D, Fong J, Black D, Ensrud K, Grady D. Urinary incontinence in older women: who is at risk? Study of Osteoporotic Fractures Research Group. Obstet Gynecol. 1996;87(1):715-721.

14. Subak LL, Richter HE, Hunskaar S. Obesity and urinary incontinence: epidemiology and clinical research update. J Urol. 2009;182(6 Suppl): S2-S7.

15. Hunskaar S. A systematic review of overweight and obesity as risk factors and targets for clinical intervention for urinary incontinence in women. Neurourol Urodyn. 2008;27(8):749-757.

16. Hannestad YS, Rortveit G, Daltveit AK, Hunskaar S. Are smoking and other lifestyle factors associated with female urinary incontinence? The Norwegian EPINCONT Study. BJOG. 2003;110(3):247-254.

17. Sampselle CM, Harlow SD, Skurnick J, Brubaker L, Bondarenko I. Urinary incontinence predictors and life impact in ethnically diverse perimenopausal women. Obstet Gynecol. 2002;100(6):1230-1238.

18. Thom DH, Brown JS. Reproductive and hormonal risk factors for urinary incontinence in later life: a review of the clinical and epidemiologic literature. J Am Geriatr Soc. 1998;46(11):1411-1417.

19. Yarnell J, Voyle G, Sweetham P, Milbank J, Richards C, Stephenson T. Factors associated with urinary incontinence in women. J Epidemiol Community Health. 1982;36(1):58-63.

20. Danforth KN, Townsend MK, Lifford K, Curhan GC, Resnick NM, Grodstein F. Risk factors for urinary incontinence among middle-aged women. Am J Obstet Gynecol. 2006;194(2):339-345.

21. Han MO, Lee NY, Park HS. Abdominal obesity is associated with stress urinary incontinence in Korean women. Int Urogynecol J Pelvic Floor Dysfunct. 2006;17(1):35-39.

22. Jackson RA, Vittinghoff E, Kanaya AM, et al. Urinary incontinence in elderly women: findings from the Health, Aging, and Body Composition Study. Obstet Gynecol. 2004;104(2):301-307.

23. Melville JL, Katon W, Delaney K, Newton K. Urinary incontinence in US women: a population-based study. Arch Intern Med. 2005;165(5):537-542.

24. Burgio KL, Matthews KA, Engel BT. Prevalence, incidence and correlates of urinary incontinence in healthy, middle-aged women. J Urol. 1991;146(5):1255-1259.

25. Kuh D, Cardozo L, Hardy R. Urinary incontinence in middle aged women: childhood enuresis and other lifetime risk factors in a British prospective cohort. J Epidemiol Community Health. 1999;53(8):453-458.

26. Nygaard I, Turvey C, Burns TL, Crischilles E, Wallace R. Urinary incontinence and depression in middle-aged United States women. Obstet Gynecol. 2003;101(1):149-156.

27. Teleman PM, Lidfeldt J, Nerbrand C, Samsioe G, Mattiasson A. Overactive bladder: prevalence, risk factors and relation to stress incontinence in middle-aged women. BJOG. 2004;111(6):600-604. 
28. Hall SA, Cinar A, Link CL, et al. Do urological symptoms cluster among women? Results from the Boston Area Community Health Survey. BJU Int. 2008;101(10):1257-1266.

29. Mishra GD, Hardy R, Cardozo L, Kuh D. Body weight through adult life and risk of urinary incontinence in middle-aged women: results from a British prospective cohort. Int $J$ Obes (Lond). 2008;32(9):1415-1422.

30. Lawrence JM, Lukacz ES, Liu IL, Nager CW, Luber KM. Pelvic floor disorders, diabetes, and obesity in women: findings from the Kaiser Permanente Continence Associated Risk Epidemiology Study. Diabetes Care. 2007;30(10):2536-2541.

31. Burgio KL, Richter HE, Clements RH, Redden DT, Goode PS. Changes in urinary and fecal incontinence symptoms with weight loss surgery in morbidly obese women. Obstet Gynecol. 2007;110(5): 1034-1040.

32. Deitel M, Stone E, Kassam HA, Wilk EJ, Sutherland DJ. Gynecologicobstetric changes after loss of massive excess weight following bariatric surgery. J Am Coll Nutr. 1988;7(2):147-153.

33. Richter HE, Burgio KL, Clements RH, Goode PS, Redden DT, Varner RE. Urinary and anal incontinence in morbidly obese women considering weight loss surgery. Obstet Gynecol. 2005;106(6): 1272-1277.

34. Laungani RG, Seleno N, Carlin AM. Effect of laparoscopic gastric bypass surgery on urinary incontinence in morbidly obese women. Surg Obes Relat Dis. 2009;5(3):334-338.

35. Wasserberg N, Petrone P, Haney M, Crookes PF, Kaufman HS. Effect of surgically induced weight loss on pelvic floor disorders in morbidly obese women. Ann Surg. 2009;249(1):72-76.

36. Waetjen LE, Liao S, Johnson WO, et al. Factors associated with prevalent and incident urinary incontinence in a cohort of midlife women: a longitudinal analysis of data: study of women's health across the nation. Am J Epidemiol. 2007;165(3):309-318.

37. Townsend MK, Danforth KN, Rosner B, Curhan GC, Resnick NM, Grodstein F. Body mass index, weight gain, and incident urinary incontinence in middle-aged women. Obstet Gynecol. 2007;110(2 Pt 1): 346-353.

38. Dallosso HM, McGrother CW, Matthews RJ, Donaldson MM. The association of diet and other lifestyle factors with overactive bladder and stress incontinence: a longitudinal study in women. BJU Int 2003;92(1):69-77.

39. McGrother CW, Donaldson MM, Hayward T, Matthews R, Dallosso HM, Hyde C. Urinary storage symptoms and comorbidities: a prospective population cohort study in middle-aged and older women. Age Ageing. 2006;35(1):16-24.

40. Komesu Y, Schrader R, Rogers R, Ketai L. Urgency urinary incontinence in women $\geq 50$ years: incidence, remission and predictors of change. Female Pelvic Med Reconstr Surg. 2011;17(1):17-23.

41. Townsend MK, Curhan GC, Resnick NM, Grodstein F. BMI, waist circumference, and incident urinary incontinence in older women. Obesity (Silver Spring). 2008;16(4):881-886.

42. Hannestad YS, Huskaar S. Waist-hip ratio associated with urinary incontinence in women. International Continence Society Annual Congress, Montreal, Canada, August 28-September 2, 2005.

43. Tennstedt SL, Link CL, Steers WD, McKinlay JB. Prevalence of and risk factors for urine leakage in a racially and ethnically diverse population of adults: the Boston Area Community Health (BACH) Survey. Am J Epidemiol. 2008;167(4):390-399.

44. Fantl JA, Wyman JF, McClish DK, et al. Efficacy of bladder training in older women with urinary incontinence. JAMA 1991;265(5):609-613.

45. Burgio KL, Robinson JC, Engel BT. The role of biofeedback in Kegel exercise training for stress urinary incontinence. Am J Obstet Gynecol. 1986;154(1):58-64.

46. Wyman J, Fantl J, McClish D, Bump R. Comparative efficacy of behavioral interventions in the management of female urinary incontinence. Continence Program for Women Research Group. Am J Obstet Gynecol. 1998;179(4):999-1007.
47. Albo ME, Richter HE, Brubaker L, et al. Burch colposuspension versus fascial sling to reduce urinary stress incontinence. $N$ Engl J Med. 2007;356(21):2143-2155.

48. Richter HE, Albo ME, Zyczynski HM, et al. Retropubic versus transobturator midurethral slings for stress incontinence. $N \mathrm{Engl} \mathrm{J} \mathrm{Med}$. 2010;362(22):2066-2076.

49. Black N, Griffiths J, Pope C. Development of a symptom severity index and a symptom impact index for stress incontinence in women. Neurourol Urodyn. 1996;15(6):630-640.

50. Leach GE, Dmochowski RR, Appell RA, et al. Female Stress Urinary Incontinence Clinical Guidelines Panel summary report on surgical management of female stress urinary incontinence. The American Urological Association. J Urol. 1997;158(3 Pt 1):875-880.

51. Lovatsis D, Gupta C, Dean E, Lee F. Tension-free vaginal tape procedure is an ideal treatment for obese patients. Am J Obstet Gynecol. 2003;189(6):1601-1604.

52. Cummings JM, Boullier JA, Parra RO. Surgical correction of stress incontinence in morbidly obese women. J Urol. 1998;160(3 Pt 1): 754-755.

53. Rafii A, Darai E, Haab F, Samain E, Levardon M, Deval B. Body mass index and outcome of tension-free vaginal tape. Eur Urol. 2003;43(3):288-292.

54. Rogers RG, Lebkuchner U, Kammerer-Doak DN, Thompson PK, Walters MD, Nygaard IE. Obesity and retropubic surgery for stress incontinence: is there really an increased risk of intraoperative complications? Am J Obstet Gynecol. 2006;195(6):1794-1798.

55. Greer WJ, Richter HE, Bartolucci AA, Burgio KL. Obesity and pelvic floor disorders: a systematic review. Obstet Gynecol. 2008;112(2 Pt 1): 341-349.

56. Haverkorn RM, Williams BJ, Kubricht WS 3rd, Gomelsky A. Is obesity a risk factor for failure and complications after surgery for incontinence and prolapse in women? J Urol. 2010;185(3):987-992.

57. Tchey DU, Kim WT, Kim YJ, Yun SJ, Lee SC, Kim WJ. Influence of obesity on short-term surgical outcome of the transobturator tape procedure in patients with stress urinary incontinence. Int Neurourol J. 2010;14(1):13-19.

58. Anderson R, Mobley D, Blank B, Saltzstein D, Susset J, Brown J. Once daily controlled versus immediate release oxybutynin chloride for urge urinary incontinence. OROS Oxybutynin Study Group. J Urol. 1999;161(6):1809-1812.

59. Appell RA. Clinical efficacy and safety of tolterodine in the treatment of overactive bladder: a pooled analysis. Urology. 1997; 50(6A Suppl):90-96.

60. Fantl J, Newman D, Colling J, DeLancey J, Keeys C, McDowell B. Urinary Incontinence in Adults: Acute and Chronic Management. Rockville, MD: agency for Health Care Policy and Research; 1996.

61. Van Kerrebroeck P, Kreder K, Jonas U, Zinner N, Wein A. Tolterodine once-daily: superior efficacy and tolerability in the treatment of the overactive bladder. Urology. 2001;57(3):414-421.

62. Lawrence M, Guay DR, Benson SR, Anderson MJ. Immediate-release oxybutynin versus tolterodine in detrusor overactivity: a population analysis. Pharmacotherapy. 2000;20(4):470-475.

63. Dmochowski RR, Appell RA. Advancements in pharmacologic management of the overactive bladder. Urology. 2000;56(6 Suppl 1): 41-49.

64. Watanabe JH, Campbell JD, Ravelo A, Chancellor MB, Kowalski J, Sullivan SD. Cost analysis of interventions for antimuscarinic refractory patients with overactive bladder. Urology. 2010;76(4):835-840.

65. Siddiqui NY, Amundsen CL, Visco AG, Myers ER, Wu JM. Cost-effectiveness of sacral neuromodulation versus intravesical botulinum A toxin for treatment of refractory urge incontinence. J Urol. 2009;182(6):2799-2804.

66. Dmochowski R, Sand PK. Botulinum toxin A in the overactive bladder: current status and future directions. BJU Int. 2007;99(2): 247-262.

67. Bump R, Sugerman H, Fantl J, McClish D. Obesity and lower urinary tract function in women: effect of surgically induced weight loss. Am J Obstet Gynecol. 1992;167(2):392-399. 
68. Sugerman H, Windsor A, Bessos M, Kellum J, Reines H, DeMaria E. Effects of surgically induced weight loss on urinary bladder pressure, sagittal abdominal diameter and obesity co-morbidity. Int J Obes Relat Metab Disord. 1998;22(3):230-235.

69. Vella VL, Jaffe W, Lidicker J, Meilahn J, Dandolu V. Prevalence of urinary symptoms in morbidly obese women and changes after bariatric surgery. J Reprod Med. 2009;54(10):597-602.

70. Srinivasa S, Hill LS, Sammour T, Hill AG, Babor R, Rahman H. Early and mid-term outcomes of single-stage laparoscopic sleeve gastrectomy. Obes Surg. 2010;20(11):1484-1490.

71. Subak LL, Johnson C, Whitcomb E, Boban D, Saxton J, Brown JS. Does weight loss improve incontinence in moderately obese women? Int J Urogyn. 2002;13(1):40-43.

72. Subak LL, Whitcomb E, Shen H, Saxton J, Vittinghoff E, Brown JS. Weight loss: a novel and effective treatment for urinary incontinence. J Urol. 2005;174(1):190-195.

73. Brown JS, Wing R, Barrett-Connor E, et al. Lifestyle intervention is associated with lower prevalence of urinary incontinence: the Diabetes Prevention Program. Diabetes Care. 2006;29(2):385-390.

74. Subak LL, Wing R, West DS, et al. Weight loss to treat urinary incontinence in overweight and obese women. $N$ Engl J Med. 2009;360(5):481-490.

75. Auwad W, Steggles P, Bombieri L, Waterfield M, Wilkin T, Freeman R. Moderate weight loss in obese women with urinary incontinence: A prospective longitudinal study. Int Urogynecol J Pelvic Floor Dysfunct. 2008;19(9):1251-1259.

76. Wing RR, West DS, Grady D, et al. Effect of weight loss on urinary incontinence in overweight and obese women: results at 12 and 18 months. J Urol. 2010;184(3):1005-1010.

77. Tyagi P, Barclay D, Zamora R, et al. Urine cytokines suggest an inflammatory response in the overactive bladder: a pilot study. Int Urol Nephrol. 2010;42(3):629-635.

78. Neels JG, Olefsky JM. Inflamed fat: what starts the fire? J Clin Invest. 2006;116(1):33-35.

79. Agur W, Rizk DE. Obesity and urinary incontinence in women: is the black box becoming grayer? Int Urogynecol J Pelvic Floor Dysfunct. 2010;22(3):257-258.

80. Rizk DE, Fahim MA. Ageing of the female pelvic floor: towards treatment a la carte of the "geripause". Int Urogynecol J Pelvic Floor Dysfunct. 2008;19(4):455-458.

81. Chancellor MB, Oefelein MG, Vasavada S. Obesity is associated with a more severe overactive bladder disease state that is effectively treated with once-daily administration of trospium chloride extended release. Neurourol Urodyn. 2010;29(4):551-554.

82. Nathan PA, Keniston RC, Myers LD, Meadows KD. Obesity as a risk factor for slowing of sensory conduction of the median nerve in industry. A cross-sectional and longitudinal study involving 429 workers. J Occup Med. 1992;34(4):379-383.

83. Cummings JM, Rodning CB. Urinary stress incontinence among obese women: review of pathophysiology therapy. Int Urogynecol J Pelvic Floor Dysfunct. 2000;11(1):41-44.

84. Noblett KL, Jensen JK, Ostergard DR. The relationship of body mass index to intra-abdominal pressure as measured by multichannel cystometry. Int Urogynecol J Pelvic Floor Dysfunct. 1997;8(6): $323-326$.
85. Richter HE, Creasman JM, Myers DL, Wheeler TL, Burgio KL, Subak LL. Urodynamic characterization of obese women with urinary incontinence undergoing a weight loss program: the Program to Reduce Incontinence by Diet and Exercise (PRIDE) trial. Int Urogynecol J Pelvic Floor Dysfunct. 2008;19(12):1653-1658.

86. Ko Y, Lin SJ, Salmon JW, Bron MS. The impact of urinary incontinence on quality of life of the elderly. Am J Manag Care. 2005; 11(4 Suppl):S103-S111.

87. Teunissen D, Van Den Bosch W, Van Weel C, Lagro-Janssen T. "It can always happen": the impact of urinary incontinence on elderly men and women. Scand J Prim Health Care. 2006;24(3):166-173.

88. Brown JS, Vittinghoff E, Wyman JF, et al. Urinary incontinence: does it increase risk for falls and fractures? Study of Osteoporotic Fractures Research Group. J Am Geriatr Soc. 2000;48(7):721-725.

89. Thom DH, Haan MN, Van Den Eeden SK. Medically recognized urinary incontinence and risks of hospitalization, nursing home admission and mortality. Age Ageing. 1997;26(5):367-374.

90. Currie CJ, McEwan P, Poole CD, Odeyemi IA, Datta SN, Morgan CL. The impact of the overactive bladder on health-related utility and quality of life. BJU Int. 2006;97(6):1267-1272.

91. Kwon BE, Kim GY, Son YJ, Roh YS, You MA. Quality of life of women with urinary incontinence: a systematic literature review. Int Neurourol J. 2010;14(3):133-138.

92. Coyne KS, Sexton CC, Kopp ZS, Ebel-Bitoun C, Milsom I, Chapple C. The impact of overactive bladder on mental health, work productivity and health-related quality of life in the UK and Sweden: results from EpiLUTS. BJU Int. March 3, 2011. [Epub ahead of print].

93. Vaughan CP, Johnson TM 2nd, Ala-Lipasti MA, et al. The prevalence of clinically meaningful overactive bladder: bother and quality of life results from the population-based FINNO study. Eur Urol. 2011;59(4):629-636.

94. Hawkins K, Pernarelli J, Ozminkowski RJ, et al. The prevalence of urinary incontinence and its burden on the quality of life among older adults with Medicare supplement insurance. Qual Life Res. 2011;20(5):723-32.

95. Chang CH, Gonzalez CM, Lau DT, Sier HC. Urinary incontinence and self-reported health among the US Medicare managed care beneficiaries. J Aging Health. 2008;20(4):405-419.

96. Huang AJ, Brown JS, Thom DH, Fink HA, Yaffe K. Urinary incontinence in older community-dwelling women: the role of cognitive and physical function decline. Obstet Gynecol. 2007;109(4):909-916.

97. Mittmann N, Trakas K, Risebrough N, Liu BA. Utility scores for chronic conditions in a community-dwelling population. Pharmacoeconomics. 1999;15(4):369-376.

98. Mo F, Choi BC, Li FC, Merrick J. Using Health Utility Index (HUI) for measuring the impact on health-related quality of Life (HRQL) among individuals with chronic diseases. Scientific World Journal. 2004;4:746-757.

99. Clinical guidelines on the identification, evaluation, and treatment of overweight and obesity in adults - The evidence report. National Institutes of Health. Obes Res. 1998;6 Suppl 2:51S-209S.

100. Frigg A, Peterli R, Peters T, et al. Reduction in co-morbidities 4 years after laparoscopic adjustable gastric banding. Obes Surg. 2004;14(2):216-223.
Open Access Journal of Urology

\section{Publish your work in this journal}

The Open Access Journal of Urology is an international, peer-reviewed, open access journal publishing original research, reports, editorials, reviews and commentaries on all aspects of adult and pediatric urology in the clinic and laboratory including the following topics: Pathology, pathophysiology of urological disease; Investigation and treatment of

\section{Dovepress}

urological disease; Pharmacology of drugs used for the treatment of urological disease. The manuscript management system is completely online and includes a very quick and fair peer-review system, which is all easy to use. Visit http://www.dovepress.com/testimonials.php to read real quotes from published authors. 